Dieter Glebe, PhD, Series Editor

\title{
Hepatitis B virus taxonomy and hepatitis B virus genotypes
}

\author{
Stephan Schaefer
}

Stephan Schaefer, Abteilung für Virologie, Institut für Medizinische Mikrobiologie, Virologie und Hygiene, Universität Rostock, Schillingallee 70, D-18057 Rostock, Germany

Correspondence to: Stephan Schaefer, Abteilung für Virologie, Institut für Medizinische Mikrobiologie, Virologie und Hygiene, Universität Rostock Schillingallee 70, D-18057 Rostock, Germany. stephan.schaefer@med.uni-rostock.de

Telephone: +49-381-4945920 Fax: +49-381-4945925

Received: 2006-09-01

Accepted: 2006-10-12

\begin{abstract}
Hepatitis B virus (HBV) is a member of the hepadnavirus family. Hepadnaviruses can be found in both mammals (orthohepadnaviruses) and birds (avihepadnaviruses). The genetic variability of HBV is very high. There are eight genotypes of HBV and three clades of HBV isolates from apes that appear to be additional genotypes of HBV. Most genotypes are now divided into subgenotypes with distinct virological and epidemiological properties. In addition, recombination among HBV genotypes increases the variability of HBV. This review summarises current knowledge of the epidemiology of genetic variability in hepadnaviruses and, due to rapid progress in the field, updates several recent reviews on HBV genotypes and subgenotypes.
\end{abstract}

(c) 2007 The WJG Press. All rights reserved.

Key words: Orthohepadnavirus; Avihepadnavirus; Hepatitis B virus; Genotype, Subgenotype; Recombination

Schaefer S. Hepatitis B virus taxonomy and hepatitis B virus genotypes. World J Gastroenterol 2007; 13(1): 14-21

http://www.wjgnet.com/1007-9327/13/14.asp

\section{INTRODUCTION}

Hepatitis B virus (HBV) is the prototype member of a steadily growing family of viruses called hepadnaviruses ${ }^{[1]}$. Hepadnaviruses can be found in both mammals (orthohepadnaviruses) and birds (avihepadnaviruses). $\mathrm{HBV}$, the hepadnavirus infecting humans, is classified into eight genotypes today. HBV genotypes differ by at least $8 \%{ }^{[2]}$. Since the first definition of the genotypes $A$, $\mathrm{B}, \mathrm{C}$ and $\mathrm{D}^{[2]}$, genotypes $\mathrm{E}^{[3]}, \mathrm{F}^{[4]}, \mathrm{G}^{[5]}$ and $\mathrm{H}^{[6]}$ have been detected. Due to the genetic diversity of HBV, numerous subgenotypes of HBV have been described ${ }^{[7]}$ (Table 1). HBV subgenotypes differ by at least $4 \%{ }^{[8]}$.

HBV genotypes and most subgenotypes show a distinct geographic distribution. In Asia, where there is a high prevalence of $\mathrm{HBV}$ carriers, strong evidence suggests that HBV genotypes influence the course of disease. Several recent reviews have summarised knowledge on different aspects of HBV genotypes ${ }^{[7-12]}$ and on hepadnaviruses that infect species other than homo sapiens ${ }^{[13-15]}$. This review will update recent developments in understanding HBV genotypes and taxonomy.

\section{TAXONOMY}

HBV is a partially double stranded virus that uses reverse transcriptase in its replication cycle. Thus, HBV is similar to many retroviruses found in animals and pararetroviruses in plants ${ }^{[16,17]}$.

After cloning and sequencing the HBV genome ${ }^{[18]}$, several related viruses were discovered in woodchucks (Marmota monax) ${ }^{[19]}$, ground squirrels (Spermophilus beecheyi) ${ }^{[20]}$ and pekin duck (Anas domesticus) ${ }^{[21]}$. Subsequently, numerous new viruses that are similar to $\mathrm{HBV}$ were found in mammals and birds and have been cloned (Tables 1 and 2). All these viruses are classified in the family of hepadnaviridae, including the genus orthohepdnavirus (mammals; Figure 1), and the genus avihepadnavirus (birds; Figure 2). In addition to the avihepadnaviruses listed in Table 2, five new hepadnaviruses were cloned from exotic duck and goose species; i.e., the Chiloe wigeon, mandarin duck, puna teal, Orinoco sheldgoose, and ashy-headed sheldgoose. Sequence comparisons revealed that 4 virus isolates were closely related to existing isolates of duck hepatitis B virus (DHBV), while the mandarin duck virus was closely related to Ross goose hepatitis B virus ${ }^{[22]}$.

In chimpanzees, gorillas, orangutans and gibbons new putative members of hepadnaviridae were discovered and sequenced completely ${ }^{[14]}$. It is now widely accepted that primate hepadnaviruses are indigenous to their hosts. Because hepadnaviruses isolated from apes are grouped as HBV genotypes in phylogenetic analyses, it has been suggested that isolates from apes should be named following the nomenclature used for immune deficiency viruses $^{[23]}$ (Table 1), e.g. HBV found in chimpanzees should be called HBVcpz. With only 5\% divergence from the chimpanzee HBV isolates, the HBV isolate from gorilla is categorized in the HBV genotype (Figure 3, unpublished 
Table 1 Orthohepadnaviruses and their host

\begin{tabular}{lll}
\hline & Host & Ref. \\
\hline Hepatitis B Virus & $\begin{array}{l}\text { Man } \\
\text { Chimpanzee Hepatitis B Virus } \\
\text { Chimpanzen sapiens } \\
\text { Pan troglodytes }\end{array}$ & {$[75]$} \\
Gibbon Hepatitis B Virus & $\begin{array}{l}\text { White handed gibbon } \\
\text { Hylobates lar } \\
\text { Orangutan }\end{array}$ & {$[77]$} \\
Orangutan Hepatitis B Virus & $\begin{array}{l}\text { Pongo pygmaeus } \\
\text { pygmaeus }\end{array}$ & {$[78]$} \\
Gorilla & $\begin{array}{l}\text { Gorilla gorilla } \\
\text { Gorilla Hepatitis B Virus }\end{array}$ & {$[79]$} \\
Woolly Monkey Hepatitis B Virus & $\begin{array}{l}\text { Woolly monkey } \\
\text { Lagothrix lagotricha } \\
\text { Woodchuck }\end{array}$ & {$[80]$} \\
Woodchuck Hepatitis Virus & $\begin{array}{l}\text { Marmota monax } \\
\text { Ground Squirrel } \\
\text { Ground Squirrel Hepatitis Virus }\end{array}$ & {$[19]$} \\
Arctic Squirrel Hepatitis Virus & $\begin{array}{l}\text { Arctic Squirrel } \\
\text { Spermophylus parryi } \\
\text { kennicotti }\end{array}$ & {$[81]$} \\
\hline
\end{tabular}

Table 2 Avihepadnaviruses and their host

\begin{tabular}{|c|c|c|}
\hline & Host & Ref. \\
\hline Duck Hepatitis B Virus & Pekin duck & [21] \\
\hline DHBV & Anas domesticus & \\
\hline $\begin{array}{l}\text { Grey Teal Hepatitis B Virus } \\
\text { (GTHBV) }\end{array}$ & $\begin{array}{l}\text { Grey Teal } \\
\text { Anas gibberifrons gracilis }\end{array}$ & [82] \\
\hline $\begin{array}{l}\text { Heron Hepatitis B Virus } \\
\text { (HHBV) }\end{array}$ & $\begin{array}{l}\text { Heron } \\
\text { Adrea cinerea }\end{array}$ & [83] \\
\hline $\begin{array}{l}\text { Maned Duck Hepatitis B Virus } \\
\text { (MDHBV) }\end{array}$ & $\begin{array}{l}\text { Maned Duck } \\
\text { Chenonetta jubata }\end{array}$ & [82] \\
\hline $\begin{array}{l}\text { Ross Goose Hepatitis Virus } \\
\text { (RGHV) }\end{array}$ & $\begin{array}{l}\text { Ross Goose } \\
\text { Anser rossi }\end{array}$ & [4] \\
\hline $\begin{array}{l}\text { Snow Goose Hepatitis B Virus } \\
\text { (SGHBV) }\end{array}$ & $\begin{array}{l}\text { Snow Goose } \\
\text { Anser caerulescens }\end{array}$ & [84] \\
\hline $\begin{array}{l}\text { Stork Hepatitis B Virus } \\
\text { (STHBV) }\end{array}$ & $\begin{array}{l}\text { White Stork } \\
\text { Ciconia ciconia }\end{array}$ & [85] \\
\hline $\begin{array}{l}\text { Crane Hepatitis B Virus } \\
\text { (CHBV) }\end{array}$ & $\begin{array}{l}\text { Demoiselle cranes } \\
\text { Anthropoides virgo } \\
\text { Grey crowned cranes } \\
\text { Balearica regulorum }\end{array}$ & [86] \\
\hline
\end{tabular}

results). Thus, three HBV genotypes from apes can now be differentiated. The chimpanzee and gorilla isolates from Africa are categorized as one genotype, i.e., HBVcpz. The isolates from the South-East-Asian apes, gibbon and orang-utan, are categorized into two genotypes, i.e., HBVgbn and HBVoru, respectively. These genotypes diverge by $8 \%$. Within the gibbon genotype, distinct strains of HBV circulating in geographically separated populations have been described ${ }^{[24]}$.

Avihepdnaviruses are the most distant relatives of HBV with a nucleic acid homology of only $40 \%$. WHV and GSHV as mammalian hepadnaviruses are more closely related to $\mathrm{HBV}$ and differ by only $17 \%$. Complete WHV and GSHV genomes from GenBank show a high degree of homology and only one genotype is listed ${ }^{[25-27]}$. However, using degenerate primers, several variant WHV

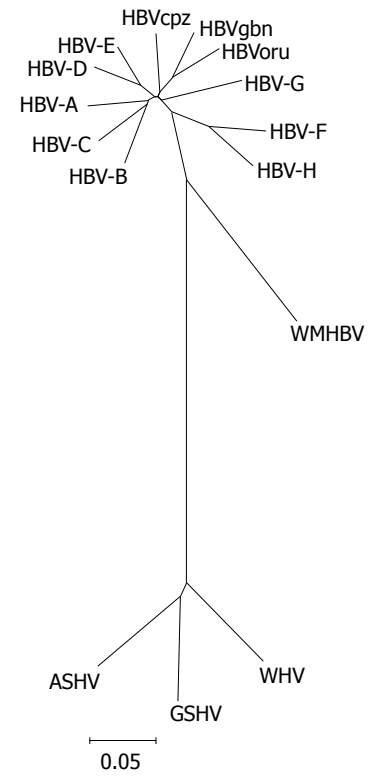

Figure 1 Phylogenetic tree of orthohepadnaviruses. Complete genomes of HBV genotypes A (X02763), B (D00330), C (M12906), D (V01460), E (X75657), F (X69798), G (AF160501) and $\mathrm{H}$ (AY090454); HBVcpz (D00220), HBVoru (NC 002168), and HBVgbn (U46935) were aligned using clustal w with orthohepadnavirus genomes from woolly monkey (AF046996) woodchuck (J02442), ground squirrel (K02715) and the tentative member from arctic squirrel (nc_001719). The alignment was tested with the neighbour-joining method.

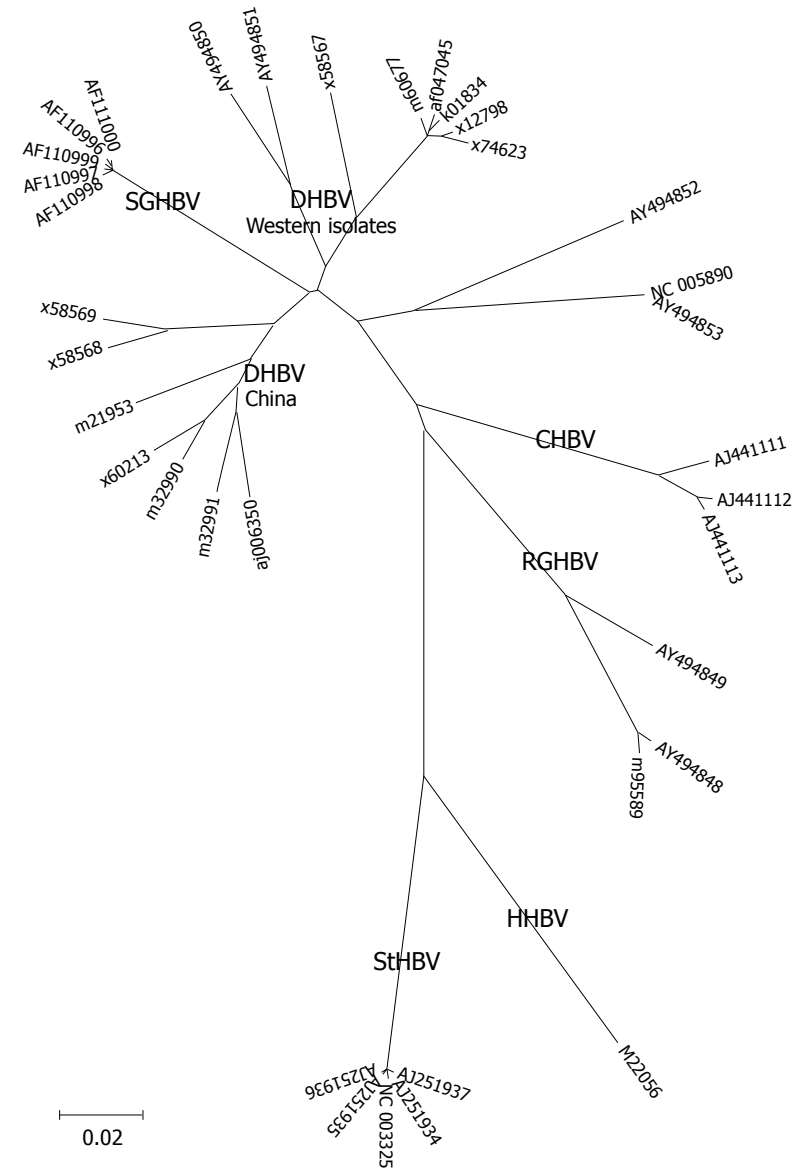

Figure 2 Phylogenetic tree of the genus avihepadnavirus.

isolates from wild-captured woodchucks were found that showed high divergence with sequencing of small parts of the genome ${ }^{[28]}$. DHBV has two genotypes, in contrast to WHV and GSHV, which have a narrow host range and geographical distribution ${ }^{[25,26]}$, DHBV is found in different avian species with independent isolates in many countries 


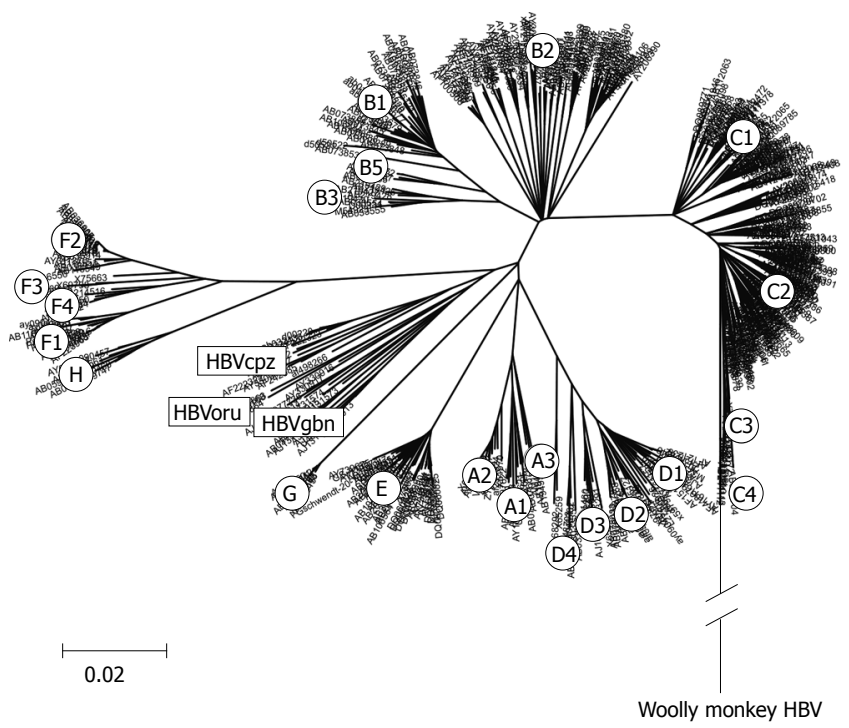

Figure 3 Phylogenetic tree of complete HBV genomes. An alignment of 601 complete HBV sequences was performed with Clustal $X$ in the program DNAstar. The alignment was further analysed by boot-strapping using the NeighbourhoodJoining method contained in MEGA version $3.1^{[104]}$.

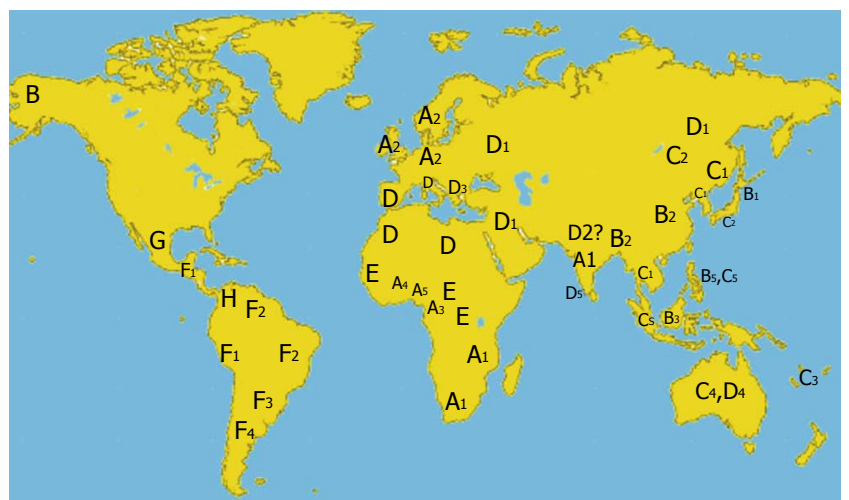

Figure 4 Geographic distribution of HBV genotypes and subgenotypes.

around the world ${ }^{[29]}$ (Figure 4).

Human HBV can be grouped into eight genotypes (based on more than $8 \%$ difference) ${ }^{[7,9-12]}$. Several attempts have been made to reconstruct the evolution of hepadnaviruses ${ }^{[30-34]}$. Estimating the rate of synonymous substitutions for HBV to be $4.57 \times 10^{-5}$ per site per year, DHBV has been proposed to have diverged about 30000 years ago from a common ancestor while GSHV and WHV should have diverged about 10000 years ago from HBV and the HBV serotypes would be separated by about 3000 years ${ }^{[31]}$. However, as long as we are not able to accurately estimate the mutation rate of $\mathrm{HBV}$ over centuries or even millennia, it is not possible to calculate a time point for the separation of HBV genotypes or hepadnaviral species.

\section{HBV GENOTYPES AND SUBGENOTYPES}

HBV genotypes differ by more than $8 \%{ }^{[2,3]}$. Phylogenetic analyses using alignments of whole genomes have shown that 8 genotypes, called A, B, C, D, E, F, G and H, of HBV
Table 3 Fundamental properties of genomes and differences between HBV genotypes

\begin{tabular}{lcl}
\hline Genotype & Genome length in bp & ORF-differences \\
\hline A & 3221 & Insertion of aa 153 and 154 in HBc \\
B & 3215 & \\
C & 3215 & \\
D & 3182 & Deletion of aa 1-11 in preS1 \\
E & 3212 & Deletion of aa 11 in preS1 \\
F & 3215 & \\
G & 3248 & Insertion of 12 aa in HBc \\
& & Deletion of aa 11 in preS1 \\
H & 3215 & \\
\hline
\end{tabular}

Table 4 HBV subgenotypes and geographic prevalence

\begin{tabular}{|c|c|c|c|c|}
\hline & Subgenotype & Synonyms & Geographic origin & Ref. \\
\hline \multirow[t]{5}{*}{ A } & A1 & $\mathrm{Aa}, \mathrm{A}^{\prime}$ & Africa, (Asia, South America) & {$[41,87]$} \\
\hline & A2 & Ae, A-A' & Europe & \\
\hline & A3 & Ac & Gabon, Cameroon & {$[88,89]$} \\
\hline & (A4) & & Mali & [59] \\
\hline & (A5) & & Nigeria & [59] \\
\hline \multirow[t]{5}{*}{ B } & B1 & $\mathrm{Bj}$ & Japan & {$[67,90]$} \\
\hline & B2 & $\mathrm{Ba}$ & Asia without Japan & \\
\hline & B3 & & Indonesia, Philippines & [7] \\
\hline & B4 & & Vietnam & [7] \\
\hline & B5 & & Philippines & {$[91,92]$} \\
\hline \multirow[t]{7}{*}{ C } & $\mathrm{C} 1$ & Cs & South East Asia (Vietnam, & {$[37-39]$} \\
\hline & & & Myanmar, Thailand, Southern & \\
\hline & & & China) & \\
\hline & $\mathrm{C} 2$ & $\mathrm{Ce}$ & $\begin{array}{l}\text { Far East (Korea, Japan, } \\
\text { Northern China) }\end{array}$ & \\
\hline & C3 & & Micronesia & [7] \\
\hline & $\mathrm{C} 4$ & & Australia & [93] \\
\hline & C5 & & Philippines, Vietnam & {$[92,94]$} \\
\hline \multirow[t]{5}{*}{$\mathrm{D}$} & D1 & & Mongolia, Belarus, Europe? & \\
\hline & D2 & & India? & \\
\hline & D3 & & South Africa, East India, Serbia & {$[40,41]$} \\
\hline & D4 & & Australia & [93] \\
\hline & D5 & & East India & [40] \\
\hline \multirow[t]{4}{*}{$\mathrm{F}$} & F1 & & South and Central America & {$[95,96]$} \\
\hline & F2 & & South America & [4] \\
\hline & F3 & & Bolivia & {$[97,98]$} \\
\hline & F4 & & Argentina & {$[97,98]$} \\
\hline
\end{tabular}

can be distinguished ${ }^{[7,11,12,35]}$ (Figure 1). In general, HBV isolates found in apes diverge similarly to HBV genotypes in phylogenetic analyses and have been named HBVcpz, -oru, -gor and -gbn for their host's, i.e. chimpanzee, orangutan, gorilla and gibbon, respectively (Table 1$)^{[23]}$. However, as elucidated above, the isolate from gorillas is always categorized into the chimpanzee clade.

A prototypic HBV genome may have a length of $3215 \mathrm{nt}$, as found in HBV genotypes B, C, F and H. Due to deletions and insertions (Table 3), the other HBV genotypes differ slightly in length of genome (Table 3). Thus HBV genotype G with 3248 nt. is 66 nt longer than genotype D with $3182 \mathrm{bp}$.

Extensive phylogenetic analyses have shown that HBV genotypes can be further subdivided into subgenotypes (Table 4). HBV subgenotypes differ by at least $4 \%{ }^{[8]}$. In 


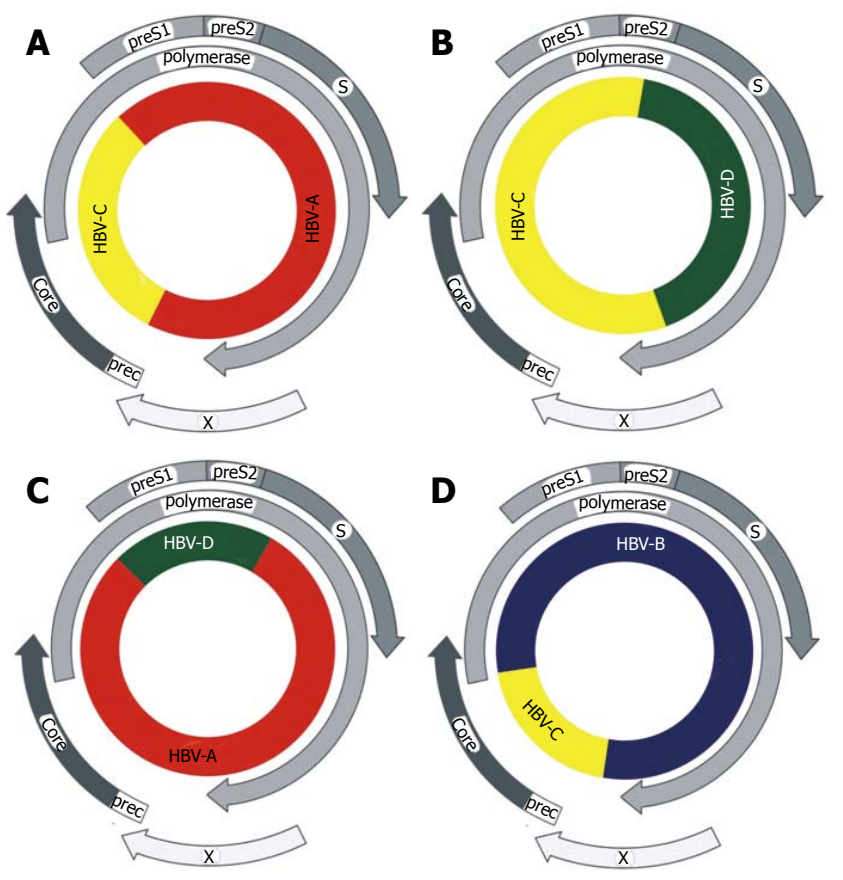

Figure 5 Schematic genome organisation of recombinants between HBV genotypes. HBV recombinants were described from materials sampled in A: Vietnam ${ }^{[99]}$; B: Tibet ${ }^{[68]}$; C: Africa ${ }^{[100]}$ and D: Asia ${ }^{[67]}$. The ORF coding for the HBV proteins are shown as arrows, the inner circle represents the HBV genome.

genotypes A, B and C, epidemiological data show that the respective subgenotype pairs A1/A2 (formerly termed $\mathrm{Aa} / \mathrm{Ae})^{[36]}, \mathrm{B} 1 / \mathrm{B} 2$ (formerly $\left.\mathrm{Bj} / \mathrm{Ba}\right)^{[36]}$ and $\mathrm{C} 1 / \mathrm{C} 2$ (formerly $\mathrm{Cs} / \mathrm{Ce})^{[37-39]}$ differ substantially in many virological and probably some clinical parameters. Subgenotypes also show distinct geographic distribution (Figure 3). However, this is not true for genotype D with subgenotypes D1, D2 and D3 being described as widespread in the world; e.g. D3 was found in Asia (East India) ${ }^{[40]}$, South Africa ${ }^{[41]}$ and Europe (Serbia) (Stanojevic et al, unpublished results).

Except for genotype E and G, all HBV genotypes can be divided into subgenotypes. The absence of subgenotypes in HBV genotype $\mathrm{E}$ has been assumed to be the consequence of a recent genesis for genotype $\mathrm{E}^{[42-45]}$. Furthermore, genotype $\mathrm{E}$ is not present in Americans of African origin from Venezuela and Brazil ${ }^{[46,47]}$. The case for HBV genotype $G$ appears to be less clear. Genotype $G$ was originally found in the USA, France ${ }^{[5]}$ and Germany ${ }^{[48]}$. Later, partial sequencing of $\mathrm{HBV}$ genes pointed to a high prevalence of HBV genotype $G$ in Mexico ${ }^{[49]}$. Nevertheless, the geographic origin of HBV genotype $G$ remains unknown ${ }^{[50]}$. To date only a limited number of complete HBV genotype $G$ sequences have been deposited in GenBank that are not classified into subgenotypes.

\section{DOUBLE INFECTIONS AND RECOMBI- NANTS}

Double infections with two different HBV genotypes have been known since typing was done serologically ${ }^{[1,52]}$. Subsequently, evidence of super infection with HBV isolates of the same or different genotype was described in
Table 5 Examples for recombination events between of HBV genotypes

\begin{tabular}{|c|c|c|c|c|c|}
\hline \multicolumn{2}{|c|}{ Genotype of } & \multicolumn{2}{|c|}{ Recombination Breakpoint } & \multirow{2}{*}{$\begin{array}{l}\text { No. } \\
\text { in literature }\end{array}$} & \multirow{2}{*}{ Ref. } \\
\hline Backbone & Insert & $5 \prime$ & $3 \prime$ & & \\
\hline A & C & 1801 & 2865 & 3 & [99] \\
\hline A & D & $\begin{array}{c}2895 \\
2820 \\
?\end{array}$ & $\begin{array}{c}327 \\
386-586 \\
670\end{array}$ & 3 & [100] \\
\hline B & C & $1740-1838$ & 2443- 2485 & 41 & {$[67,73,101,102]$} \\
\hline B & C & $\begin{array}{l}3120 \\
3060 \\
2910\end{array}$ & $\begin{array}{l}3171 \\
3191 \\
2950\end{array}$ & $\begin{array}{l}1 \\
1 \\
1\end{array}$ & [60] \\
\hline C & B & $1731-1838$ & 2437- 2479 & 1 & [102] \\
\hline D & A & $\begin{array}{l}129 \\
495 \\
822\end{array}$ & $\begin{array}{c}2339 \\
780 \\
1775\end{array}$ & 3 & {$[73,101,102]$} \\
\hline G & C & 1860 & 2460 & 1 & {$[103]$} \\
\hline A & E & 882 & 1060 & 1 & [88] \\
\hline
\end{tabular}

chronic HBV patients ${ }^{[53]}$. Super infection was accompanied by acute exacerbation of the chronic disease. Additional observations came from patients treated with interferon. Before treatment, HBV genotype A was prevalent. After treatment and relapse, a switch of the genotype to HBV genotype $\mathrm{D}$ was described ${ }^{[54,55]}$.

Using different methods for genotyping, several reports described high rates of double infection with two different HBV genotypes in all parts of the world. Using these methods double infections have been found in $4.4 \%{ }^{[56]}$, $10.9 \%{ }^{[57]}, 12.5 \%{ }^{[58]}, 14.1 \%$ (Kirschberg et al, unpublished results), $17.3 \%{ }^{[59]}$ and $17.5 \%^{[60]}$ of $\mathrm{HBV}$ infected patients. Even triple infections with $\mathrm{HBV}$ of genotype A, B and C have been described in $0.9 \%$ of $\mathrm{HBV}$ infected intravenous drug users ${ }^{[60]}$.

Infection with HBV of genotype $G$ seems to be associated very often with an infection of HBV genotype $\mathrm{A}^{[61]}$. This was found in 4 individuals from the USA and in one patient from France ${ }^{[62]}$.

Coinfection with two different HBV genotypes in one patient may lead to an exchange of genetic material between the two strains. However, with current knowledge of $\mathrm{HBV}$ replication, the mechanism for this supposed recombination remains enigmatic. No mechanism can be envisioned that would allow an exchange of genetic material between two hepadnaviral genomes at the level of transcription. Nevertheless, numerous authors described changes in the genome of HBV that appear to be the consequences of a recombinatorial event (Figure 5 and Table 5).

Two recent works have comprehensively analysed the prevalence of events in the HBV genome that are reminiscent of recombinations ${ }^{[63,64]}$. About $87 \%$ of the putative recombinants were B/C (120) and A/D (29) hybrids. The other recombinants comprised A/ B/C, A/C, A/E, A/G, C/D, C/F, C/G, C/U (U for unknown genotype) and $\mathrm{B} / \mathrm{C} / \mathrm{U}$ hybrids. Genotypes $\mathrm{A}$ and $\mathrm{C}$ showed a higher recombination tendency than $\mathrm{did}$ 
other genotypes. The results also demonstrated region priority and breakpoint hot spots in the intergenotype recombination. Recombination breakpoints were found to be concentrated mainly in the vicinity of the DR1 region (nt 1640-1900), the preS1/S2 region (nt 3150-100), the 3' -end of the Core gene (nt 2330-2450) and the 3'-end of the Surface gene (nt 650-830) ${ }^{[6,664]}$.

Recombination events between human and chimpanzee ${ }^{\left[{ }^{[65]}\right.}$ or gibbon ${ }^{[63]}$ HBV sequences have also been described. Discrepant genotyping results from different parts of the genome are indicative of a recombination between genotype $\mathrm{A}$ and $\mathrm{F}^{[6]}$. Even mosaic genomes with sequences derived from three different genotypes have been described ${ }^{[59,64]}$.

Some recombinants among HBV genotypes have become the dominant subgenotype prevalent in certain geographic regions. Recombination between genotypes B and $\mathrm{C}$ has led to the generation of two different strains with distinct geographic distribution ${ }^{[6]}$. Strains of genotype $\mathrm{B}$ without recombination are found in Japan (subgenotype $\mathrm{B} 1$ ), whereas strains with recombination between genotype $\mathrm{B}$ and $\mathrm{C}$ are found throughout Asia (subgenotype B2), sparing Japan ${ }^{[67]}$. Recombinants between HBV genotypes $\mathrm{C}$ and $\mathrm{D}$ are the leading HBV subgenotype in Tibet ${ }^{[68-70]}$.

It remains open for discussion whether the observed exchanges are the consequence of direct genetic recombination taking place between two HBV strains or if they are the consequence of fast adaptation of HBV to a certain genetic and immunologic environment in different human populations in the world. The high replication capacity of $\mathrm{HBV}$ with a release of up to $10^{13}$ viral particles per day ${ }^{[71,72]}$ and the high error rate of the viral polymerase, lead to the production of $\mathrm{HBV}$ genomes with all possible single mutations and double mutations of every nucleotide of the HBV genome every day ${ }^{[72]}$. Thus, a fast adaptation of HBV to a new environment is also a possibility.

A hypothetical mosaicism of the HBV genome has already been proposed by Bowyer and $\operatorname{Sim}^{[33]}$. This work and later works described most HBV genotypes as a modular genome ${ }^{[63]}$ that represents a mixture of small segments coming from many different HBV genotypes. If we expand on this observation, the HBV genome may be made up of a number of allelic modules with different properties; e.g. different binding sites for transcription factors or antigenic epitopes. Thus, a certain combination of these modules would make up an HBV genotype. The findings of Fischer $e t a l^{[74]}$ are in support of this speculation. The authors described genotype specific activation or repression of HBV enhancer II, preCorepregenomic promoter by the transcription factor COUPTF1.

\section{CONCLUSION}

HBV has been recognised as a prototype member of a family of viruses infecting mammals and birds. Due to its high replication capacity and the high error rate of the viral reverse transcriptase, HBV is able to adapt to the host's environment. This adaptation has led to the emergence of eight genotypes in humans and three closely related genotypes in apes. The human genotypes have further diverged into at least 24 subgenotypes, with certainly many more to come, and a plethora of recombinants. From the analysis of recombinants there are indications that at least one more genotype remains to be detected.

\section{REFERENCES}

1 Mason WS, Burrell CJ, Casey J, Gerlich WH, Howard CR, Kann M, Newbold J, Schaefer S, Taylor JM, Will H Hepadnaviridae. In: Fauquet CM, Mayo MA, Maniloff J, Desselberger U, Ball LA (editors). Virus Taxonomy. Eighth Report of the International Committee on Taxonomy of Viruses. Amsterdam: Elsevier, 2005

2 Okamoto H, Tsuda F, Sakugawa H, Sastrosoewignjo RI, Imai M, Miyakawa Y, Mayumi M. Typing hepatitis B virus by homology in nucleotide sequence: comparison of surface antigen subtypes. J Gen Virol 1988; 69 ( Pt 10): 2575-2583

3 Norder H, Couroucé AM, Magnius LO. Complete genomes, phylogenetic relatedness, and structural proteins of six strains of the hepatitis B virus, four of which represent two new genotypes. Virology 1994; 198: 489-503

4 Naumann H, Schaefer S, Yoshida CF, Gaspar AM, Repp R, Gerlich WH. Identification of a new hepatitis B virus (HBV) genotype from Brazil that expresses HBV surface antigen subtype adw4. J Gen Virol 1993; 74 (Pt 8): 1627-1632

5 Stuyver L, De Gendt S, Van Geyt C, Zoulim F, Fried M, Schinazi RF, Rossau R. A new genotype of hepatitis B virus: complete genome and phylogenetic relatedness. J Gen Virol 2000; 81: 67-74

6 Arauz-Ruiz P, Norder H, Robertson BH, Magnius LO. Genotype H: a new Amerindian genotype of hepatitis B virus revealed in Central America. J Gen Virol 2002; 83: 2059-2073

7 Norder $\mathbf{H}$, Couroucé AM, Coursaget $P$, Echevarria JM, Lee $\mathrm{SD}$, Mushahwar IK, Robertson BH, Locarnini S, Magnius LO. Genetic diversity of hepatitis B virus strains derived worldwide: genotypes, subgenotypes, and HBsAg subtypes. Intervirology 2004; 47: 289-309

8 Kramvis A, Kew MC. Relationship of genotypes of hepatitis $B$ virus to mutations, disease progression and response to antiviral therapy. J Viral Hepat 2005; 12: 456-464

9 Chu CJ, Lok AS. Clinical significance of hepatitis B virus genotypes. Hepatology 2002; 35: 1274-1276

10 Kramvis A, Kew M, François G. Hepatitis B virus genotypes. Vaccine 2005; 23: 2409-2423

11 Miyakawa Y, Mizokami M. Classifying hepatitis B virus genotypes. Intervirology 2003; 46: 329-338

12 Schaefer S. Hepatitis B virus: significance of genotypes. J Viral Hepat 2005; 12: 111-124

13 Schaefer S, Tolle T, Lottmann S, Gerlich W. Animal Models and Experimental Systems in Hepatitis B Virus Research. in: Koshy R, Caselmann W (eds). Hepatitis B Virus: Molecular Mechanisms in Disease and Novel Strategies for Therapy. London: Imperial College Press, 1998: 51-74

14 Robertson BH, Margolis HS. Primate hepatitis B viruses genetic diversity, geography and evolution. Rev Med Virol 2002; 12: 133-141

15 Burda MR, Günther S, Dandri M, Will H, Petersen J. Structural and functional heterogeneity of naturally occurring hepatitis $B$ virus variants. Antiviral Res 2001; 52: 125-138

16 Abravaya K, Huff J, Marshall R, Merchant B, Mullen C, Schneider G, Robinson J. Molecular beacons as diagnostic tools: technology and applications. Clin Chem Lab Med 2003; 41: $468-474$

17 Li MD, Bronson DL, Lemke TD, Faras AJ. Phylogenetic analyses of 55 retroelements on the basis of the nucleotide and product amino acid sequences of the pol gene. Mol Biol Evol 1995; 12: 657-670

18 Galibert F, Mandart E, Fitoussi F, Tiollais P, Charnay P. 
Nucleotide sequence of the hepatitis B virus genome (subtype ayw) cloned in E. coli. Nature 1979; 281: 646-650

19 Summers J, Smolec JM, Snyder R. A virus similar to human hepatitis B virus associated with hepatitis and hepatoma in woodchucks. Proc Natl Acad Sci USA 1978; 75: 4533-4537

20 Marion PL, Oshiro LS, Regnery DC, Scullard GH, Robinson WS. A virus in Beechey ground squirrels that is related to hepatitis B virus of humans. Proc Natl Acad Sci USA 1980; 77: 2941-2945

21 Mason WS, Seal G, Summers J. Virus of Pekin ducks with structural and biological relatedness to human hepatitis B virus. J Virol 1980; 36: 829-836

22 Guo H, Mason WS, Aldrich CE, Saputelli JR, Miller DS, Jilbert AR, Newbold JE. Identification and characterization of avihepadnaviruses isolated from exotic anseriformes maintained in captivity. J Virol 2005; 79: 2729-2742

23 Bartholomeusz A, Schaefer S. Hepatitis B virus genotypes: comparison of genotyping methods. Rev Med Virol 2004; 14: 3-16

24 Sall AA, Starkman S, Reynes JM, Lay S, Nhim T, Hunt M, Marx N, Simmonds P. Frequent infection of Hylobates pileatus (pileated gibbon) with species-associated variants of hepatitis B virus in Cambodia. J Gen Virol 2005; 86: 333-337

25 Marion PL Ground Squirrel Hepatitis Virus. in: MacLachlan A (editor). Molecular Biology of the Hepatitis B Virus. Boca Raton: CRC Press, 1991: 39-51

26 Paronetto F, Tennant BC. Woodchuck hepatitis virus infection: a model of human hepatic diseases and hepatocellular carcinoma. Prog Liver Dis 1990; 9: 463-483

27 Roggendorf $\mathbf{M}$, Tolle TK. The woodchuck: an animal model for hepatitis B virus infection in man. Intervirology 1995; 38: $100-112$

28 Huang $\mathbf{Z}$, Buckwold VE. A TaqMan PCR assay using degenerate primers for the quantitative detection of woodchuck hepatitis virus DNA of multiple genotypes. Mol Cell Probes 2005; 19: 282-289

29 Schödel F, Weimer T, Fernholz D, Schneider R, Sprengel R, Wildner G, Will H The Biology of Avian Hepatitis B Viruses. In: MacLachlan A (editor). Molecular Biology of the Hepatitis B Virus. Boca Raton: CRC Press, 1991: 53-80

30 Bollyky PL, Holmes EC. Reconstructing the complex evolutionary history of hepatitis B virus. J Mol Evol 1999; 49: 130-141

31 Orito E, Mizokami M, Ina Y, Moriyama EN, Kameshima N, Yamamoto M, Gojobori T. Host-independent evolution and a genetic classification of the hepadnavirus family based on nucleotide sequences. Proc Natl Acad Sci USA 1989; 86: 7059-7062

32 Simmonds $\mathbf{P}$. The origin and evolution of hepatitis viruses in humans. J Gen Virol 2001; 82: 693-712

33 Simmonds P. Reconstructing the origins of human hepatitis viruses. Philos Trans R Soc Lond B Biol Sci 2001; 356: 1013-1026

34 Fares MA, Holmes EC. A revised evolutionary history of hepatitis B virus (HBV). J Mol Evol 2002; 54: 807-814

35 Chu CJ, Hussain M, Lok AS. Hepatitis B virus genotype B is associated with earlier $\mathrm{HBeAg}$ seroconversion compared with hepatitis B virus genotype C. Gastroenterology 2002; 122: 1756-1762

36 Sugauchi F, Kumada H, Acharya SA, Shrestha SM, Gamutan MT, Khan M, Gish RG, Tanaka Y, Kato T, Orito E, Ueda R, Miyakawa $Y$, Mizokami M. Epidemiological and sequence differences between two subtypes (Ae and Aa) of hepatitis B virus genotype A. J Gen Virol 2004; 85: 811-820

37 Chan HL, Tsui SK, Tse CH, Ng EY, Au TC, Yuen L, Bartholomeusz A, Leung KS, Lee KH, Locarnini S, Sung JJ. Epidemiological and virological characteristics of 2 subgroups of hepatitis B virus genotype C. J Infect Dis 2005; 191: 2022-2032

38 Huy TT, Ushijima H, Quang VX, Win KM, Luengrojanakul P, Kikuchi K, Sata T, Abe K. Genotype C of hepatitis B virus can be classified into at least two subgroups. J Gen Virol 2004; 85: 283-292

39 Tanaka Y, Orito E, Yuen MF, Mukaide M, Sugauchi F, Ito K, Ozasa A, Sakamoto T, Kurbanov F, Lai CL, Mizokami M. Two subtypes (subgenotypes) of hepatitis B virus genotype C: A novel subtyping assay based on restriction fragment length polymorphism. Hepatol Res 2005; 33: 216-224

40 Banerjee A, Kurbanov F, Datta S, Chandra PK, Tanaka Y, Mizokami M, Chakravarty R. Phylogenetic relatedness and genetic diversity of hepatitis B virus isolates in Eastern India. J Med Virol 2006; 78: 1164-1174

41 Kimbi GC, Kramvis A, Kew MC. Distinctive sequence characteristics of subgenotype A1 isolates of hepatitis B virus from South Africa. J Gen Virol 2004; 85: 1211-1220

42 Fujiwara K, Tanaka Y, Orito E, Ohno T, Kato T, Sugihara K, Hasegawa I, Sakurai M, Ito K, Ozasa A, Sakamoto Y, Arita I, El-Gohary A, Benoit A, Ogoundele-Akplogan SI, Yoshihara N, Ueda R, Mizokami M. Distribution of HBV genotypes among HBV carriers in Benin:phylogenetic analysis and virological characteristics of HBV genotype E. World J Gastroenterol 2005; 11: 6410-6415

43 Huy TT, Ishikawa K, Ampofo W, Izumi T, Nakajima A, Ansah J, Tetteh JO, Nii-Trebi N, Aidoo S, Ofori-Adjei D, Sata T, Ushijima H, Abe K. Characteristics of hepatitis B virus in Ghana: full length genome sequences indicate the endemicity of genotype E in West Africa. J Med Virol 2006; 78: 178-184

44 Kramvis A, Restorp K, Norder H, Botha JF, Magnius LO, Kew MC. Full genome analysis of hepatitis B virus genotype E strains from South-Western Africa and Madagascar reveals low genetic variability. J Med Virol 2005; 77: 47-52

45 Mulders MN, Venard V, Njayou M, Edorh AP, Bola Oyefolu AO, Kehinde MO, Muyembe Tamfum JJ, Nebie YK, Maiga I, Ammerlaan W, Fack F, Omilabu SA, Le Faou A, Muller CP. Low genetic diversity despite hyperendemicity of hepatitis B virus genotype E throughout West Africa. J Infect Dis 2004; 190: $400-408$

46 Motta-Castro AR, Martins RM, Yoshida CF, Teles SA, Paniago AM, Lima KM, Gomes SA. Hepatitis B virus infection in isolated Afro-Brazilian communities. J Med Virol 2005; 77: 188-193

47 Quintero A, Martínez D, Alarcón De Noya B, Costagliola A, Urbina L, González N, Liprandi F, Castro De Guerra D, Pujol FH. Molecular epidemiology of hepatitis B virus in AfroVenezuelan populations. Arch Virol 2002; 147: 1829-1836

48 Vieth S, Manegold C, Drosten C, Nippraschk T, Günther S. Sequence and phylogenetic analysis of hepatitis $\mathrm{B}$ virus genotype G isolated in Germany. Virus Genes 2002; 24: 153-156

49 Sánchez LV, Maldonado M, Bastidas-Ramírez BE, Norder $\mathrm{H}$, Panduro A. Genotypes and S-gene variability of Mexican hepatitis B virus strains. J Med Virol 2002; 68: 24-32

50 Lindh M. HBV genotype G-an odd genotype of unknown origin. J Clin Virol 2005; 34: 315-316

51 Hess G, Arnold W, Koesters W, Biswas R, Hütteroth TH, zum Büschenfelde KH. Simultaneous presence of HBsAg and anti-HBs in the serum of different subtypes (serological and immunofluorescent studies). Z Immunitatsforsch Immunobiol 1977; 153: 143-151

52 Tabor E, Gerety RJ, Smallwood LA, Barker LF. Coincident hepatitis B surface antigen and antibodies of different subtypes in human serum. J Immunol 1977; 118: 369-370

53 Kao JH, Chen PJ, Lai MY, Chen DS. Acute exacerbations of chronic hepatitis $B$ are rarely associated with superinfection of hepatitis B virus. Hepatology 2001; 34: 817-823

54 Gerner PR, Friedt M, Oettinger R, Lausch E, Wirth S. The hepatitis B virus seroconversion to anti-HBe is frequently associated with HBV genotype changes and selection of preS2defective particles in chronically infected children. Virology 1998; 245: 163-172

55 Hannoun C, Krogsgaard K, Horal P, Lindh M. Genotype mixtures of hepatitis B virus in patients treated with interferon. J Infect Dis 2002; 186: 752-759

56 Ding $\mathrm{X}, \mathrm{Gu} \mathrm{H}$, Zhong $\mathrm{ZH}$, Zilong $\mathrm{X}$, Tran HT, Iwaki $\mathrm{Y}$, Li TC, Sata T, Abe K. Molecular epidemiology of hepatitis viruses and genotypic distribution of hepatitis $B$ and $C$ viruses in Harbin, China. Jpn J Infect Dis 2003; 56: 19-22

57 Kato H, Orito E, Sugauchi F, Ueda R, Koshizaka T, Yanaka S, Gish RG, Kurbanov F, Ruzibakiev R, Kramvis A, Kew MC, Ahmad N, Khan M, Usuda S, Miyakawa Y, Mizokami M. Frequent coinfection with hepatitis $\mathrm{B}$ virus strains of distinct 
genotypes detected by hybridization with type-specific probes immobilized on a solid-phase support. J Virol Methods 2003; 110: 29-35

58 Osiowy C, Giles E. Evaluation of the INNO-LiPA HBV genotyping assay for determination of hepatitis B virus genotype. $J$ Clin Microbiol 2003; 41: 5473-5477

59 Olinger CM, Venard V, Njayou M, Oyefolu AO, Maïga I, Kemp AJ, Omilabu SA, le Faou A, Muller CP. Phylogenetic analysis of the precore/core gene of hepatitis B virus genotypes E and A in West Africa: new subtypes, mixed infections and recombinations. J Gen Virol 2006; 87: 1163-1173

60 Chen BF, Kao JH, Liu CJ, Chen DS, Chen PJ. Genotypic dominance and novel recombinations in HBV genotype $\mathrm{B}$ and $\mathrm{C}$ coinfected intravenous drug users. J Med Virol 2004; 73: 13-22

61 Kato H, Orito E, Gish RG, Bzowej N, Newsom M, Sugauchi F, Suzuki S, Ueda R, Miyakawa Y, Mizokami M. Hepatitis B e antigen in sera from individuals infected with hepatitis $B$ virus of genotype G. Hepatology 2002; 35: 922-929

62 Kremsdorf D, Garreau F, Capel F, Petit MA, Brechot C. In vivo selection of a hepatitis $\mathrm{B}$ virus mutant with abnormal viral protein expression. J Gen Virol 1996; 77 (Pt 5): 929-939

63 Simmonds $\mathbf{P}$, Midgley S. Recombination in the genesis and evolution of hepatitis B virus genotypes. J Virol 2005; 79: 15467-15476

64 Yang J, Xing K, Deng R, Wang J, Wang X. Identification of Hepatitis $B$ virus putative intergenotype recombinants by using fragment typing. J Gen Virol 2006; 87: 2203-2215

65 Magiorkinis EN, Magiorkinis GN, Paraskevis DN, Hatzakis AE. Re-analysis of a human hepatitis B virus (HBV) isolate from an East African wild born Pan troglodytes schweinfurthii: evidence for interspecies recombination between HBV infecting chimpanzee and human. Gene 2005; 349: 165-171

66 Gutiérrez C, Devesa M, Loureiro CL, León G, Liprandi F, Pujol FH. Molecular and serological evaluation of surface antigen negative hepatitis B virus infection in blood donors from Venezuela. J Med Virol 2004; 73: 200-207

67 Sugauchi F, Orito E, Ichida T, Kato H, Sakugawa H, Kakumu S, Ishida T, Chutaputti A, Lai CL, Ueda R, Miyakawa Y, Mizokami M. Hepatitis B virus of genotype B with or without recombination with genotype $C$ over the precore region plus the core gene. J Virol 2002; 76: 5985-5992

68 Cui C, Shi J, Hui L, Xi H, Zhuoma G. The dominant hepatitis B virus genotype identified in Tibet is a C/D hybrid. J Gen Virol 2002; 83: 2773-2777

69 Wang Z, Liu Z, Zeng G, Wen S, Qi Y, Ma S, Naoumov NV, Hou J. A new intertype recombinant between genotypes $C$ and D of hepatitis B virus identified in China. J Gen Virol 2005; 86: $985-990$

70 Zeng G, Wang Z, Wen S, Jiang J, Wang L, Cheng J, Tan D, Xiao F, Ma S, Li W, Luo K, Naoumov NV, Hou J. Geographic distribution, virologic and clinical characteristics of hepatitis B virus genotypes in China. J Viral Hepat 2005; 12: 609-617

71 Nowak MA, Bonhoeffer S, Hill AM, Boehme R, Thomas HC, McDade H. Viral dynamics in hepatitis B virus infection. Proc Natl Acad Sci USA 1996; 93: 4398-4402

72 Brechtbuehl K, Whalley SA, Dusheiko GM, Saunders NA. A rapid real-time quantitative polymerase chain reaction for hepatitis B virus. J Virol Methods 2001; 93: 105-113

73 Bowyer SM, Sim JG. Relationships within and between genotypes of hepatitis B virus at points across the genome: footprints of recombination in certain isolates. J Gen Virol 2000; 81: 379-392

74 Fischer SF, Schmidt K, Fiedler N, Glebe D, Schüttler C, Sun J, Gerlich WH, Repp R, Schaefer S. Genotype-dependent activation or repression of HBV enhancer II by transcription factor COUP-TF1. World I Gastroenterol 2006; 12: 6054-6058

75 Dane DS, Cameron $\mathrm{CH}$, Briggs M. Virus-like particles in serum of patients with Australia-antigen- associated hepatitis. Lancet 1970; 1: 695-698

76 Vaudin M, Wolstenholme AJ, Tsiquaye KN, Zuckerman AJ, Harrison TJ. The complete nucleotide sequence of the genome of a hepatitis B virus isolated from a naturally infected chim- panzee. J Gen Virol 1988; 69 (Pt 6): 1383-1389

77 Norder H, Ebert JW, Fields HA, Mushahwar IK, Magnius LO. Complete sequencing of a gibbon hepatitis $\mathrm{B}$ virus genome reveals a unique genotype distantly related to the chimpanzee hepatitis B virus. Virology 1996; 218: 214-223

78 Warren KS, Heeney JL, Swan RA, Heriyanto EJ. A new group of hepadnaviruses naturally infecting orangutans (Pongo pygmaeus). J Virol 1999; 73: 7860-7865

79 Grethe S, Heckel JO, Rietschel W, Hufert FT. Molecular epidemiology of hepatitis B virus variants in nonhuman primates. $J$. Virol. 2000; 74: 5377- 5381

80 Lanford RE, Chavez D, Brasky KM, Burns RB, Rico-Hesse R. Isolation of a hepadnavirus from the woolly monkey, a New World primate. Proc Natl Acad Sci USA 1998; 95: 5757-5761

81 Testut P, Renard CA, Terradillos O, Vitvitski-Trepo L, Tekaia F, Degott C, Blake J, Boyer B, Buendia MA. A new hepadnavirus endemic in arctic ground squirrels in Alaska. J Virol 1996; 70: 4210-4219

82 Li L, Dixon RJ, Gu X, Newbold JE: Comparison of the sequences of the Grey Teal, Maned Duck and Duck Hepatitis B Viruses. In The molecular biology of Hepatitis B Virus. The United States: University of California San Diego, 1998: 13

83 Sprengel R, Kaleta EF, Will H. Isolation and characterization of a hepatitis B virus endemic in herons. J Virol 1988; 62: 3832-3839

84 Chang SF, Netter HJ, Bruns M, Schneider R, Frölich K, Will H. A new avian hepadnavirus infecting snow geese (Anser caerulescens) produces a significant fraction of virions containing single-stranded DNA. Virology 1999; 262: 39-54

85 Pult I, Netter HJ, Fröhlich K, Kaleta EF, Will H: Identification, structural and functional analysis of a new avian Hepadnavirus from storks (STHBV). In The molecular biology of Hepatitis B Virus. The United States: University of California San Diego, 1998: 2

86 Prassolov A, Hohenberg H, Kalinina T, Schneider C, Cova L, Krone O, Frölich K, Will H, Sirma H. New hepatitis B virus of cranes that has an unexpected broad host range. J Virol 2003; 77: 1964-1976

87 Kramvis A, Weitzmann L, Owiredu WK, Kew MC. Analysis of the complete genome of subgroup $\mathrm{A}^{\prime}$ hepatitis $\mathrm{B}$ virus isolates from South Africa. J Gen Virol 2002; 83: 835-839

88 Kurbanov F, Tanaka Y, Fujiwara K, Sugauchi F, Mbanya D, Zekeng L, Ndembi N, Ngansop C, Kaptue L, Miura T, Ido E, Hayami M, Ichimura H, Mizokami M. A new subtype (subgenotype) Ac (A3) of hepatitis $B$ virus and recombination between genotypes A and E in Cameroon. J Gen Virol 2005; 86: 2047-2056

89 Makuwa M, Souquière S, Telfer P, Apetrei C, Vray M, Bedjabaga I, Mouinga-Ondeme A, Onanga R, Marx PA, Kazanji M, Roques $\mathrm{P}$, Simon $\mathrm{F}$. Identification of hepatitis $\mathrm{B}$ virus subgenotype A3 in rural Gabon. J Med Virol 2006; 78: 1175-1184

90 Sugauchi F, Orito E, Ichida T, Kato H, Sakugawa H, Kakumu S, Ishida T, Chutaputti A, Lai CL, Gish RG, Ueda R, Miyakawa Y, Mizokami M. Epidemiologic and virologic characteristics of hepatitis B virus genotype B having the recombination with genotype C. Gastroenterology 2003; 124: 925-932

91 Nagasaki F, Niitsuma H, Cervantes JG, Chiba M, Hong S, Ojima T, Ueno Y, Bondoc E, Kobayashi K, Ishii M, Shimosegawa T. Analysis of the entire nucleotide sequence of hepatitis $B$ virus genotype B in the Philippines reveals a new subgenotype of genotype B. J Gen Virol 2006; 87: 1175-1180

92 Sakamoto T, Tanaka Y, Orito E, Co J, Clavio J, Sugauchi F, Ito K, Ozasa A, Quino A, Ueda R, Sollano J, Mizokami M. Novel subtypes (subgenotypes) of hepatitis $\mathrm{B}$ virus genotypes $\mathrm{B}$ and $\mathrm{C}$ among chronic liver disease patients in the Philippines. J Gen Virol 2006; 87: 1873-1882

93 Sugauchi F, Mizokami M, Orito E, Ohno T, Kato H, Suzuki S, Kimura Y, Ueda R, Butterworth LA, Cooksley WG. A novel variant genotype $C$ of hepatitis $B$ virus identified in isolates from Australian Aborigines: complete genome sequence and phylogenetic relatedness. J Gen Virol 2001; 82: 883-892

94 Cavinta L, Sun J, Zarnekow M, Barzaga N, Schaefer S. New 
hepatitis B virus subgenotype C5 from the Philippines. submitted

95 Kato H, Fujiwara K, Gish RG, Sakugawa H, Yoshizawa H, Sugauchi F, Orito E, Ueda R, Tanaka Y, Kato T, Miyakawa Y, Mizokami M. Classifying genotype $\mathrm{F}$ of hepatitis $\mathrm{B}$ virus into F1 and F2 subtypes. World J Gastroenterol 2005; 11: 6295-6304

96 Norder H, Arauz-Ruiz P, Blitz L, Pujol FH, Echevarria JM, Magnius LO. The $\mathrm{T}(1858)$ variant predisposing to the precore stop mutation correlates with one of two major genotype $\mathrm{F}$ hepatitis B virus clades. J Gen Virol 2003; 84: 2083-2087

97 Devesa M, Rodríguez C, León G, Liprandi F, Pujol FH. Clade analysis and surface antigen polymorphism of hepatitis B virus American genotypes. J Med Virol 2004; 72: 377-384

98 Huy TT, Ushijima H, Sata T, Abe K. Genomic characterization of HBV genotype $\mathrm{F}$ in Bolivia: genotype $\mathrm{F}$ subgenotypes correlate with geographic distribution and $\mathrm{T}(1858)$ variant. Arch Virol 2006; 151: 589-597
99 Hannoun C, Norder H, Lindh M. An aberrant genotype revealed in recombinant hepatitis $\mathrm{B}$ virus strains from Vietnam. J Gen Virol 2000; 81: 2267-2272

100 Owiredu WK, Kramvis A, Kew MC. Hepatitis B virus DNA in serum of healthy black African adults positive for hepatitis B surface antibody alone: possible association with recombination between genotypes A and D. J Med Virol 2001; 64: 441-454

101 Bollyky PL, Rambaut A, Harvey PH, Holmes EC. Recombination between sequences of hepatitis $\mathrm{B}$ virus from different genotypes. J Mol Evol 1996; 42: 97-102

102 Morozov V, Pisareva M, Groudinin M. Homologous recombination between different genotypes of hepatitis B virus. Gene 2000; 260: 55-65

103 Suwannakarn K, Tangkijvanich $\mathrm{P}$, Theamboonlers A, Abe K, Poovorawan Y. A novel recombinant of Hepatitis B virus genotypes $\mathrm{G}$ and $\mathrm{C}$ isolated from a Thai patient with hepatocellular carcinoma. J Gen Virol 2005; 86: 3027-3030

104 Kumar S, Tamura K, Nei M. MEGA3: Integrated software for Molecular Evolutionary Genetics Analysis and sequence alignment. Brief Bioinform 2004; 5: 150-163

S- Editor Liu Y L- Editor Lutze M E- Editor Ma WH 